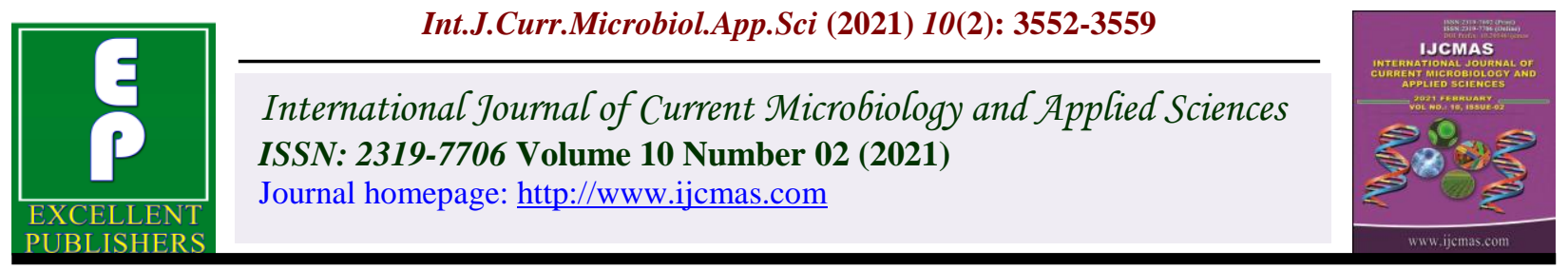

Original Research Article

https://doi.org/10.20546/ijcmas.2021.1002.391

\title{
Response of Integrated Source of Nutrients on Growth and Yield Attributes of Alstroemeria cv. 'Capri'
}

\author{
Shweta Sharma*, Sabhya Pathania and B.P. Sharma
}

Department of Floriculture and Landscape Architecture, Dr YSP University of Horticulture and Forestry, Nauni, Solan, Himachal Pradesh-173 230, India

*Corresponding author

Keywords

Alstroemeria,

Panchgavya,

Jeevamrit and

Biostimulants

Article Info

Accepted:

28 January 2021

Available Online:

10 February 2021

A B S T R A C T

The present investigation was carried out to evaluate the response of integrated source of nutrients on growth and yield attributes of Alstroemeria cv. 'Capri' under shade net condition in mid hill zone of H.P. The experiment was laid out in randomized block design comprising 20 treatment combinations of NPK and biostimulants viz., (Panchgavya and jeevamrit) which were applied at different concentrations and replicated thrice. The data pertaining to various growth and yield parameters was recorded for consecutive 4 flushes. The study revealed that all the growth and yield parameters exhibited positive response to combined application of NPK with panchgavya. Maximum weight (62.74 g), yield (101.08) and vase life of cut stems (18.08 days) as well as length $(28.45 \mathrm{~cm})$ and weight of rhizome $(823.53 \mathrm{~g})$ developed per plant was recorded in treatment comprising of $100 \%$ NPK (RDF) $+75 \mathrm{ml}$ panchgavya.

\section{Introduction}

Alstroemeria (Alstroemeria hybridaL.) has developed worldwide importance as a cut flower crop due to its excellent vase life, diversified range of colours, low energy growing requirement and high productivity. The genus is a rhizomatous monocot, belongs to family alstroemeriaceae and has about 93 species which are mostly found in Chile and Brazil. It is native to South America and commonly known as 'the Peruvian Lily' or 'Lily of Incas' (Singh et al., 2007). A large number of cultivars have been bred through hybridization and mutagenesis and are being cultivated for cut flower production and as pot plants.

The popularity of this flower is still growing and it has attained the status of one of the ten most important cut flowers in the world. It is mainly propagated by division of the fleshy 
underground sympodial rhizomes from which aerial shoots arise. The rhizomes develop into vertical shoots and later generate lateral rhizomes which produce flowering shoots.

Nutrition is one of the important aspects of crop growth. Application of nutrients at required quantity and at the right period is highly essential as it directly affects the yield. Conventional agriculture has made an adverse impact on soil and plant health. The continuous and unbalanced use of conventional fertilizers leads to decreased nutrient uptake efficiency of plants resulting in decreased crop yield (Baruati, et al., 2018).

At this juncture, a keen awareness has sprung on adoption of such holistic approach, where we first know what exactly is required by the plant for an optimum level of production, in what different forms these nutrients should be applied in the soil, at what different timings and how best these forms should be integrated to obtain highest productive efficiency on economically acceptable limits in environment friendly manner (Baraily and Deb, 2018).

Potential alternatives like biostimulants in conjunction with inorganic fertilizers are route to overcome this problem in a sustainable way. Organic liquids like panchgavya and jeevamrit contain microbial consortia, macronutrients, essential micronutrients and plant growth promoting substances including immunity enhancer, when these are properly mixed and incubated for recommended period it has miraculous effects on crop yield (Yadav et al., 2019).

The importance of biostimulants lies in their ability to promote hormonal activity in plants. It improves physico-chemical and biological properties of soil, besides improving the efficiency of applied nutrients. To maintain long term soil health and productivity there is an urgent need for integrated management through biostimulants apart from inorganic fertilizers (Mondel et al., 2003) considering the above facts, the present study was planned with the objective to assess the response of integrated source of nutrients on growth and yield attributes of Alstroemeria cv. 'Capri'.

\section{Materials and Methods}

To accomplish the present study, the experiment was laid out in a randomized block design consisting of 20 treatment combinations replicated thrice. The crop was grown under Shade net condition (75\% shade).

The details of treatments were: $\mathrm{T}_{1}: 100 \%$ $\mathrm{RDF}$ (Control), $\mathrm{T}_{2}: 75 \%$ of RDF, $\mathrm{T}_{3}: 25 \mathrm{ml}$ Jeevamrit, $\mathrm{T}_{4}: \quad 50 \mathrm{ml}$ Jeevamrit, $\mathrm{T}_{5}: 75 \mathrm{ml}$ Jeevamrit, $\mathrm{T}_{6}: 25 \mathrm{ml}$ Panchgavya, $\mathrm{T}_{7}: 50 \mathrm{ml}$ Panchgavya, $\mathrm{T}_{8}: 75 \mathrm{ml}$ Panchgavya, $\mathrm{T}_{9}: 100$ $\% \mathrm{RDF}+25 \mathrm{ml}$ Jeevamrit $\mathrm{T}_{10}: 100 \% \mathrm{RDF}+50$ $\mathrm{ml}$ Jeevamrit, $\mathrm{T}_{11}: 100 \% \mathrm{RDF}+75 \quad \mathrm{ml}$ Jeevamrit, $\quad \mathrm{T}_{12}: 100 \quad \% \quad \mathrm{RDF}+25 \quad \mathrm{ml}$ Panchgavya $\quad \mathrm{T}_{13}: 100 \% \mathrm{RDF}+50 \quad \mathrm{ml}$ Panchgavya, $\mathrm{T}_{14}: \quad 100 \quad \% \quad \mathrm{RDF}+75 \quad \mathrm{ml}$ Panchgavya, $\mathrm{T}_{15}: 75 \%$ of $\mathrm{RDF}+25 \mathrm{ml}$ Jeevamrit, $\mathrm{T}_{16}: \quad 75 \%$ of $\mathrm{RDF}+50 \mathrm{ml}$ Jeevamrit, $\mathrm{T}_{17}: \quad 75 \%$ of $\mathrm{RDF}+75 \mathrm{ml}$ Jeevamrit, $\mathrm{T}_{18}: \quad 75 \%$ of $\mathrm{RDF}+25 \mathrm{ml}$ Panchgavya, $\mathrm{T}_{19}$ : $75 \%$ of $\mathrm{RDF}+50 \mathrm{ml}$ Panchgavya and $\mathrm{T}_{20}$ : $75 \%$ of RDF+75 ml Panchgavya. The selected healthy and disease-free plants of alstroemeria (Alstroemeria hybrida) cv. 'Capri' were planted at a spacing of $50 \mathrm{~cm} \times 50 \mathrm{~cm}$ with a density of four plants per meter square having beds of size of $1 \mathrm{~m} \mathrm{x} 1 \mathrm{~m}$.

The recommended dose of fertilizer applied was N: P: K @ 150: 100: 150 ppm. Panchgavya and jeevamrit were prepared according to the standard methodology as recommended by Palekar (2006). The treatment combinations were applied at 
fortnightly intervals and data was recorded for various growth and yield attributes for consecutive 4 flushes.

\section{Results and Discussion}

\section{Effect of NPK and biostimulants on yield attributes}

The perusal of the study revealed that attributes like weight of cut stems, yield of cut stems and vase life of cut stems was significantly influenced by application of different nutritional treatments. In general, maximum yield (101.08), weight of (62.74 g) and vase life (18.08 days) of cut stems was recorded in treatment $\mathrm{T}_{14}(100 \% \mathrm{RDF}+75 \mathrm{ml}$ Panchgavya) (Table 1 and 2).

As regards to influence of flushes, maximum yield (92.50), weight $(57.90 \mathrm{~g})$, and vase life (16.97 days) of cut stems was exhibited during $3^{\text {rd }}$ flush. Similar trends were observed for interaction effects between treatment $\mathrm{x}$ flush. Maximum yield (118.67), weight (66.91g) and vase life (20.00 days) of cut stems was recorded in treatment $\mathrm{T}_{14}(100 \%$ $\mathrm{RDF}+75 \mathrm{ml}$ Panchgavya) during $3^{\text {rd }}$ flush.

Better yield attributes during $3^{\text {rd. }}$ flush is ascribed to enhanced growth of plants due to efficient nutrient uptake and better soil physico - chemical properties. The increase in yield attributes might be due improvement in the nutrient availability of the plant by addition of atmospheric nitrogen to the soil which promote vegetative growth and yield of the plant.

The conversion of photosynthates into proteins results in more flower primordia and development of flower buds, which result in higher flower yield (Pansuriya et al., 2018).

Further, increase in weight of cut stems may be due to manifestation of various growth and yield attributing characters. This was ascribed to cementing action of polysaccharides and other organic compounds released during the decomposition and fermentation of organic liquids in conjunction with inorganic fertilizers thus, leading to increased growth, yield and weight of cut stems.

Enhanced vase life may be attributed to higher doses of NPK applied in short intervals. The results are in consent with the findings of Gaurav et al., (2008) in gerbera, Kumar et al., (2011) and Baruati et al., (2018) in gladiolus.

\section{Rhizome attributes}

It is evident from the data that different nutritional treatments had significant effect on rhizome attributes like size (length) of rhizomes developed per plant and weight of rhizomes developed per plant.

Maximum length of rhizomes $(28.45 \mathrm{~cm})$ wasrecorded in treatment $\mathrm{T}_{14}(100 \% \mathrm{RDF}+75$ $\mathrm{ml}$ Panchgavya) and was found to be statistically at par $(27.78 \mathrm{~cm})$ with treatment $\mathrm{T}_{13}$ (100\% RDF+50 ml Panchgavya).

Whereas, minimum length of rhizomes (19.25 $\mathrm{cm})$ was recorded in treatment $\mathrm{T}_{3}(25 \mathrm{ml}$ Jeevamrit) and was found to be statistically at par $(20.12 \mathrm{~cm}$ and $20.28 \mathrm{~cm})$ with treatments $\mathrm{T}_{4}\left(50 \mathrm{ml}\right.$ Jeevamrit) and $\mathrm{T}_{5}(75 \mathrm{ml}$ Jeevamrit $)$ respectively. As regards to flushes, maximum length of rhizome $(26.46 \mathrm{~cm})$ was registered during $4^{\text {th }}$ flush whereas, it was minimum $(19.85 \mathrm{~cm})$ during $1^{\text {st }}$ flush.

Treatment $\mathrm{x}$ flushes interaction revealed that maximum length of rhizome $(30.90 \mathrm{~cm})$ was recorded in treatment $\mathrm{T}_{14}(100 \% \mathrm{RDF}+75 \mathrm{ml}$ Panchgavya) during $4^{\text {th }}$ flush and was significantly superior over all the other interactions. 
Similarly, treatment $\mathrm{T}_{14}(100 \% \mathrm{RDF}+75 \mathrm{ml}$ Panchgavya,) recorded maximum weight of rhizome $(823.53 \mathrm{~g})$ whereas, minimum weight of rhizome $(527.78 \mathrm{~g})$ was registered in treatment $\mathrm{T}_{3}(25 \mathrm{ml}$ Jeevamrit). With regards to flushes it was observed that, maximum weight of rhizomes (768.29 g) was recorded during $4^{\text {th }}$ flush and was significantly superior over all the other flushes.

Interaction between treatment $\mathrm{x}$ flush revealed that maximum weight of rhizomes $(893.69 \mathrm{~g})$ was recorded in treatment $\mathrm{T}_{14}(100 \%$ $\mathrm{RDF}+75 \mathrm{ml}$ Panchgavya) during $4^{\text {th }}$ flush and was significantly superior over all the other interactions.

However, minimum weight of rhizomes
(436.15 g) was registered in treatment $\mathrm{T}_{3}(25$ $\mathrm{ml}$ Jeevamrit) during $1^{\text {st }}$ flush.Increase in size and weight of rhizomes developed per plant is attributed to improvement in physicochemical properties of the soil due to continuous supply of available nutrient in organic and inorganic forms.

Further, enhanced water penetration, better root zone development and mobilization of reserve food material to the sink through increased activity by hydrolyzing and oxidizing enzymes might have contributed in bigger size rhizomes. (Pansuriya et al.2018).

The results are in consonance with the earlier findings of Bhalla et al., (2006), Kumar et al., (2012) and Pandey et al., (2013) in gladiolus.

Table.1

\begin{tabular}{|c|c|c|c|c|c|c|c|c|c|c|}
\hline \multirow[b]{2}{*}{ Treatments } & \multicolumn{4}{|c|}{ Yield of cut stems } & \multirow[t]{2}{*}{ Mean } & \multicolumn{4}{|c|}{$\begin{array}{l}\text { Vase life of cut stems } \\
2018 \\
\text { Mean }\end{array}$} & \multirow[t]{2}{*}{2019} \\
\hline & F1 & F2 & F3 & F4 & & F1 & F2 & F3 & F4 & \\
\hline $\begin{array}{l}\mathrm{T}_{1}: 100 \% \mathrm{RDF} \\
\text { (Control) }\end{array}$ & 68.00 & 52.67 & 90.67 & 81.33 & 73.17 & 13.30 & 12.13 & 15.81 & 12.67 & 13.58 \\
\hline $\mathrm{T}_{2}: 75 \%$ of RDF & 65.70 & 52.00 & 86.67 & 77.50 & 70.47 & 13.33 & 11.67 & 15.33 & 12.73 & 13.25 \\
\hline $\mathrm{T}_{3}: 25 \mathrm{ml}$ Jeevamrit & 46.67 & 33.33 & 56.00 & 58.67 & 48.67 & 10.67 & 9.96 & 12.85 & 11.33 & 11.00 \\
\hline $\mathrm{T}_{4:} 50 \mathrm{ml}$ Jeevamrit & 49.17 & 33.33 & 70.70 & 61.50 & 53.68 & 11.33 & 9.23 & 13.23 & 11.20 & 11.33 \\
\hline $\mathrm{T}_{5}: 75 \mathrm{ml}$ Jeevamrit & 56.10 & 40.00 & 70.87 & 72.00 & 59.74 & 11.67 & 9.97 & 13.24 & 11.56 & 11.67 \\
\hline $\begin{array}{l}\mathrm{T}_{6}: 25 \mathrm{ml} \\
\text { Panchgavya }\end{array}$ & 62.67 & 48.00 & 70.67 & 72.00 & 63.33 & 12.76 & 10.33 & 14.15 & 12.09 & 12.33 \\
\hline $\begin{array}{l}\mathrm{T}_{7}: 50 \mathrm{ml} \\
\text { Panchgavya }\end{array}$ & 62.71 & 49.33 & 76.50 & 73.50 & 65.50 & 13.46 & 11.03 & 15.33 & 12.33 & 13.08 \\
\hline $\begin{array}{l}\mathrm{T}_{8}: 75 \mathrm{ml} \\
\text { Panchgavya }\end{array}$ & 65.30 & 52.00 & 85.17 & 73.50 & 68.99 & 13.53 & 11.73 & 15.69 & 12.89 & 13.08 \\
\hline $\begin{array}{l}\mathrm{T}_{9}: 100 \% \mathrm{RDF}+25 \\
\text { ml Jeevamrit }\end{array}$ & 78.67 & 65.50 & 102.67 & 92.00 & 84.71 & 17.00 & 15.00 & 18.67 & 16.33 & 16.75 \\
\hline $\begin{array}{l}\mathrm{T}_{10}: 100 \% \mathrm{RDF}+50 \\
\text { ml Jeevamrit }\end{array}$ & 81.33 & 66.67 & 104.17 & 94.33 & 86.63 & 17.67 & 15.47 & 19.00 & 16.29 & 17.25 \\
\hline
\end{tabular}




\begin{tabular}{|c|c|c|c|c|c|c|c|c|c|c|}
\hline $\begin{array}{l}\mathrm{T}_{11}: 100 \% \mathrm{RDF}+75 \\
\text { ml Jeevamrit }\end{array}$ & 88.00 & 74.67 & 106.67 & \begin{tabular}{|l|}
97.33 \\
\end{tabular} & 91.67 & 18.00 & 15.67 & 19.33 & 16.08 & 17.42 \\
\hline $\begin{array}{l}\mathrm{T}_{12}: 100 \% \mathrm{RDF}+25 \\
\text { ml Panchgavya }\end{array}$ & 93.33 & 77.33 & 109.33 & 104.00 & 96.00 & 18.04 & 15.98 & 19.67 & 17.00 & 17.58 \\
\hline $\begin{array}{l}\mathrm{T}_{13}: 100 \% \text { RDF+50 } \\
\text { ml Panchgavya }\end{array}$ & 93.33 & 76.67 & 116.00 & 105.33 & 97.83 & 18.33 & 16.00 & 19.54 & 17.02 & 17.75 \\
\hline $\begin{array}{l}\mathrm{T}_{14}: 100 \% \text { RDF+75 } \\
\mathrm{ml} \mathrm{Panchgavya}\end{array}$ & 97.33 & 80.00 & 118.67 & 108.33 & 101.08 & 18.67 & 16.33 & 20.00 & 17.33 & 18.08 \\
\hline $\begin{array}{l}\mathrm{T}_{15}: 75 \% \text { of } \\
\mathrm{RDF}+25 \mathrm{ml} \\
\text { Jeevamrit }\end{array}$ & 70.67 & 54.67 & 93.33 & 86.67 & 76.33 & 14.00 & 13.83 & 16.70 & 13.00 & 14.08 \\
\hline $\begin{array}{l}\mathrm{T}_{16} 75 \% \text { of } \\
\mathrm{RDF}+50 \mathrm{ml} \\
\text { Jeevamrit }\end{array}$ & 76.17 & 60.00 & 94.67 & 88.33 & 79.79 & 16.10 & 13.93 & 18.02 & 15.00 & 15.58 \\
\hline $\begin{array}{l}\mathrm{T}_{17} 75 \% \text { of } \\
\mathrm{RDF}+75 \mathrm{ml} \\
\text { Jeevamrit }\end{array}$ & 76.00 & 62.00 & 97.33 & 88.67 & 80.50 & 16.33 & 13.90 & 18.21 & 15.83 & 15.83 \\
\hline $\begin{array}{l}\mathrm{T}_{18}: 75 \% \text { of } \\
\mathrm{RDF}+25 \mathrm{ml} \\
\text { Panchgavya }\end{array}$ & 77.33 & 59.09 & 98.67 & 88.00 & 81.00 & 16.00 & 14.00 & 18.33 & 15.33 & 16.00 \\
\hline $\begin{array}{l}\mathrm{T}_{19}: 75 \% \text { of } \\
\mathrm{RDF}+50 \mathrm{ml} \\
\text { Panchgavya }\end{array}$ & 78.67 & 61.33 & 100.00 & 88.83 & 82.21 & 16.33 & 14.33 & 18.45 & 16.00 & 16.25 \\
\hline $\begin{array}{l}\mathrm{T}_{20}: 75 \% \text { of } \\
\mathrm{RDF}+75 \mathrm{ml} \\
\text { Panchgavya }\end{array}$ & 78.67 & 62.67 & 101.33 & 92.17 & 83.71 & 16.97 & 15.00 & 18.33 & 16.33 & 16.58 \\
\hline Mean & 73.29 & 58.01 & 92.50 & 85.20 & & 15.15 & 13.15 & 16.97 & 14.43 & \\
\hline \multicolumn{6}{|l|}{$\mathrm{CD}_{0.05}$} & \multicolumn{5}{|l|}{$\mathrm{CD}_{0.05}$} \\
\hline \multicolumn{5}{|c|}{$\begin{array}{l}\text { Treatment:0.66 } \\
\text { Flush: 0.29 } \\
\text { Treatment X Flush: } 1.32\end{array}$} & & \multicolumn{5}{|c|}{$\begin{array}{l}\text { Treatment: } 1.46 \\
\text { Flush: } 0.65 \\
\text { Treatment X Flush: NS }\end{array}$} \\
\hline
\end{tabular}


Table.2

\begin{tabular}{|c|c|c|c|c|c|c|c|c|c|c|}
\hline \multirow[b]{2}{*}{ Treatments } & \multicolumn{4}{|c|}{$\begin{array}{l}\text { Size of Rhizome developed per } \\
\text { plant (g) } \\
2018\end{array}$} & \multirow[t]{2}{*}{ Mean } & \multicolumn{4}{|c|}{$\begin{array}{l}\text { Weight of Rhizome developed } \\
\text { per plant (g) } \\
2018\end{array}$} & \multirow[t]{2}{*}{ Mean } \\
\hline & F1 & F2 & F3 & F4 & & F1 & F2 & F3 & F4 & \\
\hline $\begin{array}{l}\mathrm{T}_{1}: 100 \% \mathrm{RDF} \\
\text { (Control) }\end{array}$ & 17.93 & 20.93 & 23.30 & 24.70 & 21.72 & 605.60 & 661.36 & 751.12 & 752.90 & 692.75 \\
\hline $\mathrm{T}_{2}: 75 \%$ of RDF & 17.53 & 20.53 & 22.70 & 24.10 & 21.22 & 555.45 & 611.31 & 701.07 & 706.96 & 643.70 \\
\hline $\begin{array}{l}\mathrm{T}_{3}: 25 \mathrm{ml} \\
\text { Jeevamrit }\end{array}$ & 15.50 & 18.50 & 20.80 & 22.20 & 19.25 & 436.15 & 496.51 & 586.27 & 592.16 & 527.78 \\
\hline $\begin{array}{l}\mathrm{T}_{4:} 50 \mathrm{ml} \\
\text { Jeevamrit }\end{array}$ & 16.37 & 19.37 & 21.67 & 23.07 & 20.12 & 443.74 & 504.10 & 593.86 & 599.75 & 535.36 \\
\hline $\begin{array}{l}\mathrm{T}_{5}: 75 \mathrm{ml} \\
\text { Jeevamrit }\end{array}$ & 16.53 & 19.53 & 21.83 & 23.23 & 20.28 & 452.17 & 511.95 & 601.71 & 602.36 & 542.04 \\
\hline $\begin{array}{l}\mathrm{T}_{6}: 25 \mathrm{ml} \\
\text { Panchgavya }\end{array}$ & 17.03 & 20.03 & 22.33 & 23.73 & 20.78 & 495.87 & 555.65 & 645.41 & 646.06 & 585.75 \\
\hline $\begin{array}{l}\mathrm{T}_{7}: 50 \mathrm{ml} \\
\text { Panchgavya }\end{array}$ & 17.10 & 20.10 & 22.47 & 23.87 & 20.88 & 515.82 & 575.60 & 665.36 & 666.01 & 605.69 \\
\hline $\begin{array}{l}\mathrm{T}_{8}: 75 \mathrm{ml} \\
\text { Panchgavya }\end{array}$ & 17.17 & 20.17 & 22.67 & 24.07 & 21.02 & 543.23 & 599.09 & 688.85 & 692.61 & 630.95 \\
\hline $\begin{array}{l}\mathrm{T}_{9}: 100 \% \\
\mathrm{RDF}+25 \mathrm{ml} \\
\text { Jeevamrit }\end{array}$ & 22.10 & 25.10 & 27.40 & 28.80 & 25.85 & 698.05 & 753.91 & 852.07 & 846.41 & 787.61 \\
\hline $\begin{array}{l}\mathrm{T}_{10}: 100 \% \\
\mathrm{RDF}+50 \mathrm{ml} \\
\text { Jeevamrit }\end{array}$ & 22.40 & 25.40 & 27.70 & 29.10 & 26.15 & 713.00 & 768.86 & 867.02 & 851.52 & 800.10 \\
\hline $\begin{array}{l}\mathrm{T}_{11}: 100 \% \\
\mathrm{RDF}+75 \mathrm{ml} \\
\text { Jeevamrit }\end{array}$ & 22.50 & 25.50 & 28.07 & 29.47 & 26.38 & 720.88 & 776.74 & 874.90 & 859.40 & 807.98 \\
\hline $\begin{array}{l}\mathrm{T}_{12}: 100 \% \\
\mathrm{RDF}+25 \mathrm{ml} \\
\text { Panchgavya }\end{array}$ & 23.03 & 26.03 & 28.33 & 29.73 & 26.78 & 724.10 & 779.96 & 884.59 & 869.09 & 814.44 \\
\hline $\begin{array}{l}\mathrm{T}_{13}: 100 \% \\
\mathrm{RDF}+50 \mathrm{ml} \\
\text { Panchgavya }\end{array}$ & 24.33 & 26.93 & 29.23 & 30.63 & 27.78 & 725.96 & 781.82 & 886.45 & 870.95 & 816.30 \\
\hline $\begin{array}{l}\mathrm{T}_{14:}: 100 \% \\
\mathrm{RDF}+75 \mathrm{ml} \\
\text { Panchgavya }\end{array}$ & 26.07 & 27.33 & 29.50 & 30.90 & 28.45 & 733.20 & 789.06 & 893.69 & 878.19 & 823.53 \\
\hline $\begin{array}{l}\mathrm{T}_{15}: 75 \% \text { of } \\
\mathrm{RDF}+25 \mathrm{ml} \\
\text { Jeevamrit }\end{array}$ & 18.00 & 21.00 & 23.50 & 24.90 & 21.85 & 615.62 & 671.48 & 761.24 & 763.02 & 702.84 \\
\hline $\mathrm{T}_{16} 75 \%$ of & 19.17 & 22.17 & 24.33 & 25.73 & 22.85 & 655.50 & 711.36 & 801.12 & 802.90 & 742.72 \\
\hline
\end{tabular}




\begin{tabular}{|c|c|c|c|c|c|c|c|c|c|c|}
\hline $\begin{array}{l}\mathrm{RDF}+50 \mathrm{ml} \\
\text { Jeevamrit }\end{array}$ & & & & & & & & & & \\
\hline $\begin{array}{l}\mathrm{T}_{17} 75 \% \text { of } \\
\mathrm{RDF}+75 \mathrm{ml} \\
\text { Jeevamrit }\end{array}$ & 19.80 & 22.80 & 25.10 & 26.50 & 23.55 & 665.23 & 721.09 & 810.85 & 816.74 & 753.48 \\
\hline $\begin{array}{l}\mathrm{T}_{18}: 75 \% \text { of } \\
\mathrm{RDF}+25 \mathrm{ml} \\
\text { Panchgavya }\end{array}$ & 21.30 & 24.30 & 26.60 & 28.00 & 25.05 & 678.02 & 733.88 & 823.64 & 829.53 & 766.26 \\
\hline $\begin{array}{l}\mathrm{T}_{19}: 75 \% \text { of } \\
\mathrm{RDF}+50 \mathrm{ml} \\
\text { Panchgavya }\end{array}$ & 21.33 & 24.33 & 26.63 & 28.03 & 25.08 & 690.50 & 746.36 & 836.12 & 836.57 & 777.39 \\
\hline $\begin{array}{l}\mathrm{T}_{20}: 75 \% \text { of } \\
\text { RDF+75 ml } \\
\text { Panchgavya }\end{array}$ & 21.77 & 24.77 & 27.07 & 28.47 & 25.52 & 694.90 & 750.76 & 840.52 & 842.01 & 782.05 \\
\hline Mean & 19.85 & 22.74 & 25.06 & 26.46 & & 618.15 & 675.04 & 768.29 & 766.26 & \\
\hline $\begin{array}{l}\mathrm{CD}_{0.05} \\
\text { Treatment: } 1.18 \\
\text { Flush: } 0.53 \\
\text { Treatment X Flush: }\end{array}$ & NS & & & & & $\begin{array}{l}\text { CD }_{0.05} \\
\text { Treatm } \\
\text { Flush: } \\
\text { Treatm }\end{array}$ & $\begin{array}{l}29 \\
29 \\
\text { X Flu }\end{array}$ & 5.75 & & \\
\hline
\end{tabular}

It is concluded that from the present study, it is concluded that application of $100 \%$ RDF i.e. N: P: K @ 150: 100: 150 ppm + 75 ml panchgavya is found effective in improving growth, flowering and yield attributes of alstroemeria plants cv. 'Capri.'

\section{References}

Baraily P and Deb P. 2018. Effect of integrated nutrient management on growth and yield of pineapple (cv. Kew). International Journal of chemical studies 6 (5): 1691-1695.

Baruati D, Choudhury M and Kumar V.2018. Effect of organic manures and biofertilizers on growth and yield of gladiolus (Gladiolus grandiflorus L.) International Journal of chemical studies 6 (5): 2529-2532.

Bhalla R, Kanwar P, Dhiman SR and Jain R.2006. Effect of biofertilizers and biostimulants on growth and flowering of gladiolus. Journal of Ornamental
Horticulture 9 (4): 248-252.

Gaurav SB, Singh BR, Kakaije DS, Patil MT and Ranpise SA.2008. Integrated nutrient management in gerbera. In Book of abstracts. National Symposium on recent advances in Floriculture 4-6 March Navsari. pp 45.

Kumar R, Kumar R and Kumar P. 2011. Effect of intergrated use of chemical fertilizers, biofertilizers and biostimulants in gladiolus (Gladiolus grandiflorus L.) cv. Sancerre. Progressive Horticulture 43 (1): 149152.

Mondel T, Ghanti P, Mahato B, Mondel AR and Thapa U. 2003. Effect of spacing and biofertilizer on yield and yield attributes of direct sown Chilly.Env Eco21:712-715.

Palekar S. 2006. Text book on Shoonya Bandovalada Naisargika Krushi. Swamy Anand, Agri Prakashana, Bangalore.

Pandey A, Singh AK, Sisodia A. 2013.Effect 
of vermicompost and biostimulants on growth and flowering of gladiolus. Asian Journal of Horticulture 8 (1): 4649.

Pansuriya, P. B. and Chauhan, R. V. 2015. Effect of integrated nutrient management on growth, yield and quality of gladiolus (Gladiolus grandiflorus L.) cv. Psittacinus Hybrid. Journal of Horticulture 2:128-135.

Singh M K, Ram R and Kumar S. 2007. Impact of length of rhizome and number of feeder roots for successful survival in three Alstroemeria (Alstroemeria hybrids) cultivars plants. Journal of Ornamental Horticulture 10: 46-48.

Yadav S,Kanawjia A, Chaurasiya R, Sharma A, Padhiary Gand Yadav Anil Kumar.2019.

Response of bio-enhancer on growth and yield of tomato [Solanum lycopersicum (L.) Mill]. International Journal of chemical studies 7 (3): 180-184.

\section{How to cite this article:}

Shweta Sharma, Sabhya Pathania and Sharma, B.P. 2021. Response of Integrated Source of Nutrients on Growth and Yield Attributes of Alstroemeria cv. 'Capri'. Int.J.Curr.Microbiol.App.Sci. 10(02): 3552-3559. doi: https://doi.org/10.20546/ijcmas.2021.1002.391 